\title{
Synthesis and extraction properties of some lariat ethers derived from the spontaneously resolved guaifenesin, 3-(2-methoxyphenoxy)propane-1,2-diol
}

\author{
Zemfira A. Bredikhina, Rimma M. Eliseenkova, Robert R. Fayzullin, \\ Viktorina G. Novikova, Sergey V. Kharlamov, Dilyara R. Sharafutdinova, \\ Shamil K. Latypov and Alexander A. Bredikhin*
}

A.E. Arbuzov Institute of Organic and Physical Chemistry, Russian Academy of Sciences, Arbuzov St., 8, Kazan 420088, Russian Federation

E-mail: baa@iopc.ru

\begin{abstract}
Capable of spontaneous resolution rac-3-(2-methoxyphenoxy)propane-1,2-diol, guaifenesin 1 has been proposed as a cheap and readily available enantiopure precursor for the synthesis of nonracemic crown ethers having ligating OAr and OMe arms (lariat ethers). The crowns studied failed to form stable host/guest complexes with amine hydrochloride salts; the effective complexation was achieved using hexafluorophosphate salts. Moderate enantiomeric recognition of $\mathrm{R}^{*} \mathrm{NH}_{2} \cdot \mathrm{HPF}_{6}$ was achieved with the lariat ethers 11c. As a whole, the enantioselectivity of the extraction is inversely related to the extractive power of the lariat ether.
\end{abstract}

Keywords: Lariat ethers, guaifenesin, extraction, chiral recognition

\section{Introduction}

Cyclic polyethers (crowns) are one of the most popular classes of the synthetic receptors capable of selective binding and transport of organic and inorganic ions and molecules. ${ }^{1}$ Some nonracemic chiral (usually simply named as "chiral") crowns show a capacity for chiral recognition and predominantly bind one of the pair of enantiomers. ${ }^{2}$ The first chiral crown ethers were prepared by Cram et al. ${ }^{3}$ These enantiopure macrocycles showed from moderate to significant enantiomeric recognition toward biologically interesting ammonium guests. ${ }^{4}$ By now a large number of different crown ethers have been synthesized and studied for molecular recognition toward free and protonated chiral amino acid esters and/or other amines. ${ }^{5,6}$

An effective chiral recognition requires that a chiral receptor would be capable of forming sufficiently stable complexes with substrate enantiomers and that a chiral barrier would be present, which reduces the stability of one of the diastereomeric complexes thus formed. It is 
agreed that the binding abilities of chiral crown ethers could be enhanced particularly by the presence of a flexible side arm with an electron donor site (the case of so called lariat ethers). ${ }^{7}$

The lariat ethers chiral recognition ability towards amino acid derivatives was recently investigated. ${ }^{8}$ The common feature of the studied crowns was the presence in their structure of the chiral $\mathrm{OCH}_{2} \mathrm{C} * \mathrm{H}\left(\mathrm{CH}_{2} \mathrm{OC}_{6} \mathrm{H}_{4} \mathrm{OMe}-p\right) \mathrm{O}$ unit, the fragment of 3-(4-methoxyphenoxy)propane1,2-diol. The last compound has been prepared through $p$-methoxyphenol addition to $(S)$ glycidol.

In the early work of Gokel et al. ${ }^{9}$ it was found that within the pair of 15-crown-5 lariat ethers having $\left(\mathrm{CH}_{2} \mathrm{OC}_{6} \mathrm{H}_{4} \mathrm{OMe}\right)$ side arms, the ortho-methoxy derivative was much more effective host for sodium cation than the para-methoxy one. The obvious reason for this lies in the fact that two oxygen atoms of the substituent could be involved in the cation binding in the case of ortho, whereas the oxygen atom of the $p$-methoxyl could not be involved in this complexation by steric reasons. Having these facts in mind we decided that 3-(2-methoxyphenoxy)propane-1,2-diol 1, chiral drug guaifenesin, would be the more suitable starting material for the synthesis of the lariat ethers capable of chiral recognition.

Some years ago we have disclosed the conglomerate-forming nature of guaifenesin and developed cheap and very effective resolution procedure based on this property. ${ }^{10}$ In the present investigation we have used both enantiomers of guaifenesin prepared through entrainment procedure for construction of the series of nonracemic lariat crown ethers. In addition to that, the binding and chiral recognition ability of the so obtained hosts with respect to $\alpha$ phenylethylammonium salts and two $\alpha$-amino acid methyl ester salts is discussed here.

\section{Results and Discussion}

\section{Synthesis}

For the synthesis of chiral lariat ethers 9-11 the documented general approaches were used. ${ }^{8 a, 11-13}$ Scheme 1 is representative of the major synthetic sequences.

Both enantiomers of the key starting diol guaifenesin 1 were obtained through spontaneous resolution of the racemic material according to our published procedure. ${ }^{10}$ Both enantiomeric building block diols 3 were prepared by the reaction of diol $\mathbf{1}$ and tosylate $\mathbf{4}$, which in turn was obtained via dihydropyranyl monoprotection of ethylene glycol. ${ }^{8 a}$

Macrocycles 9 and 10 have been synthesized in 15-31\% yield by the ring closure of chiral subunit diol 1 with tri- or tetraethylene glycol di(p-toluenesulfonate) in the presence of $\mathrm{NaH}$ in THF under high dilution conditions. The 18-membered cyclic ethers 11a,b and the 20-membered cyclic ethers 11c have been synthesized by the reaction of enantiomerically pure diols $\mathbf{1}$ or $\mathbf{3}$ with the appropriate ditosylates $\mathbf{6}$ or $\mathbf{8}$ in the presence of base. The ditosylates $\mathbf{6 a - c}$ were synthesized by the reactions of dihydroxyaromatic compounds, such as catechol 2a, 2,3dihydroxynaphthalene $\mathbf{2 b}$ and 1,1'-bi-2-naphthol $(S)$-2c with ethylene oxide or chloroethanol followed by the interaction of the obtained diols 5 with $p$-toluenesulfonylchloride. 

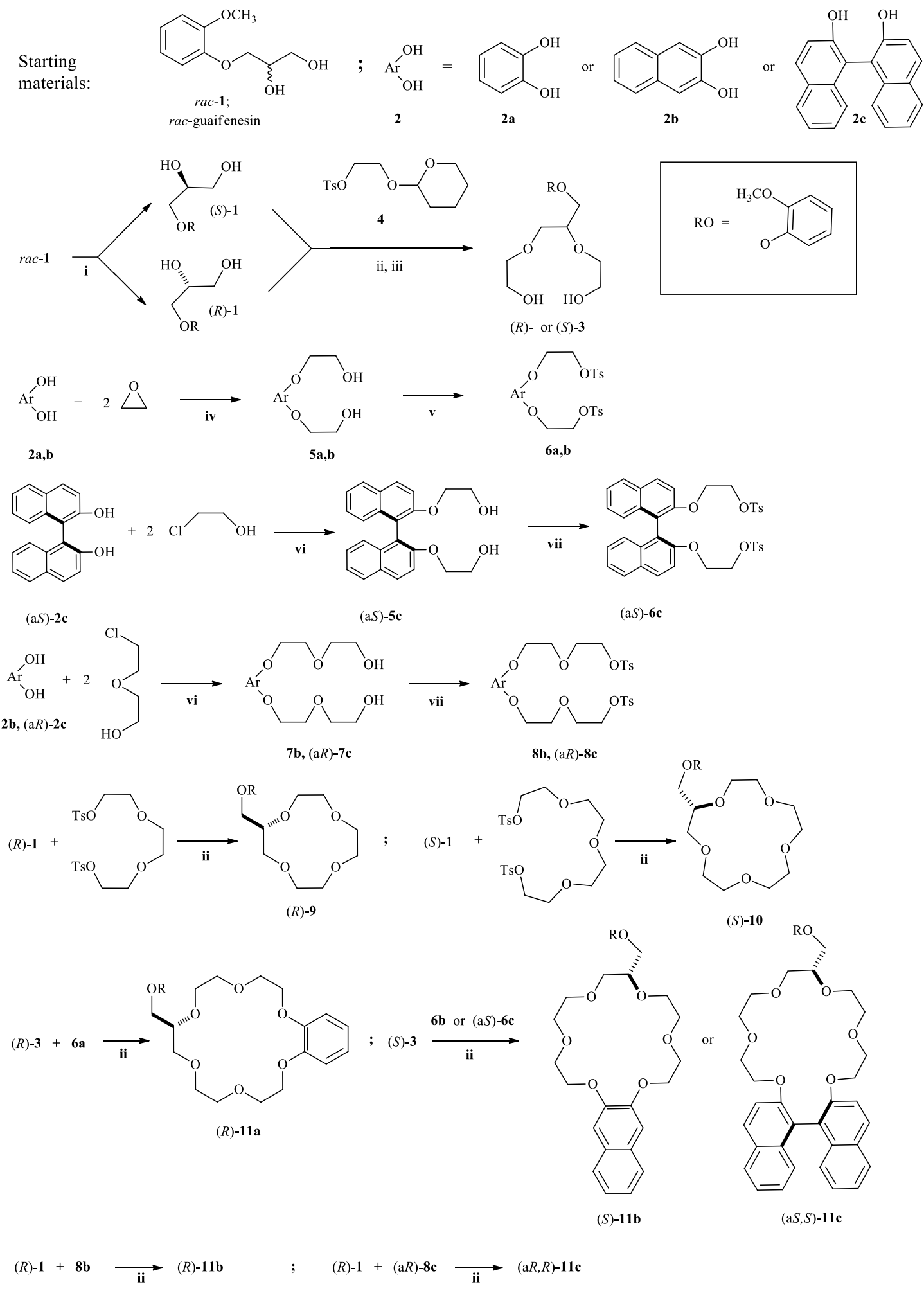

Scheme 1. Reagents and conditions: (i) preferential crystallization; (ii) NaH, THF, reflux; (iii) $\mathrm{HCl}, \mathrm{MeOH}$; (iv) piperidine hydrochloride; (v) TsCl, Py; (vi) $\mathrm{K}_{2} \mathrm{CO}_{3}$, DMF, $110{ }^{\circ} \mathrm{C}$; (vii) $\mathrm{TsCl}$, DMAP, $\mathrm{Et}_{3} \mathrm{~N}, \mathrm{CH}_{2} \mathrm{Cl}_{2}$, r.t. 
The crown ether $(R)$-11a was prepared by ring closure of diol $(R)-\mathbf{3}$ with ditosylate $\mathbf{6 a}$ in $15 \%$ yield. The crown ethers $(S)$-11b and (aS,S)-11c were prepared by ring closure of diol $(S)-\mathbf{3}$ with ditosylate $\mathbf{6 b}$ or $(\mathrm{a} S)-\mathbf{6 c}$ in $21 \%$ and $17 \%$ yield, respectively. The yield of the crowns increased approximately two times if the cyclization of diol and ditosylate $\mathbf{8}$ was explored. Thus, the crown ethers $(R)-\mathbf{1 1 b}$ and $(\mathrm{a} R, R)$-11c were prepared by ring closure of diol $(R)-\mathbf{1}$ with ditosylate $\mathbf{8 b}$ or $(\mathrm{a} R)-\mathbf{8 c}$ in $44 \%$ and $41 \%$ yield, respectively.

Lariat ethers 10, 11b, and 11c were prepared as both enantiomers. Only $(R)$-enantiomers were obtained in the case of 9 and 11a. Crowns 11c contain two different chirality elements in their structures, the centre and the axis. The last element is the attribute of nonracemic $(\mathrm{a} R)-$ or $(\mathrm{a} S)$-BINOL 2c. We have tested only enantiomeric (aR,R)- and $(\mathrm{a} S, S)$-diastereomers.

For the purpose of comparison the extraction effectiveness of the lariat ethers with OMe group in ortho- and para-position in the benzene ring we have prepared also $(S)$-[(4-methoxyphenoxy)methyl]-15-crown-5, (S)-10a; the compound was synthesized through the above outlined approach starting with $(S)$-3-(4-methoxyphenoxy)propane-1,2-diol $(S)$-1a.

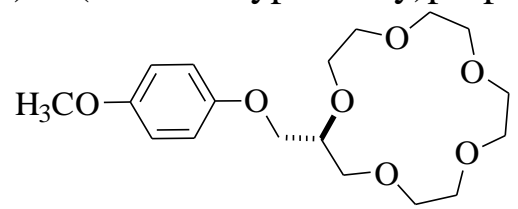

(S)-10a

The structures of the all obtained lariat ethers were consistent with the ${ }^{1} \mathrm{H}$ NMR, ${ }^{13} \mathrm{C}$ NMR and mass spectra.

\section{Molecular recognition. ${ }^{1} \mathrm{H}$ NMR experiments}

We have employed NMR spectroscopy to detect and quantify molecular recognition of lariat ethers 9-11 as host molecules. The set of chiral guests investigated in our paper consists of alanine and phenylglycine methyl esters 12 and 13, and $\alpha$-phenylethylamine 14.

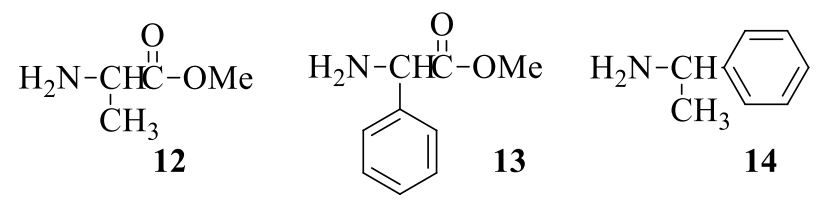

Scheme 2. Guest molecules studied.

In attempt to find the evidences of the supramolecular binding between the lariat ethers and amine guests we have investigated $\mathrm{CDCl}_{3}$ solutions of $(R)-\mathbf{1 0}$ and hydrochlorides of $\mathbf{1 2}$ and $\mathbf{1 4}$. It was found that ${ }^{1} \mathrm{H}$ chemical shifts perturbations $\left({ }^{1} \mathrm{H}\right.$ CSPs $)$ in $(R)-\mathbf{1 0}+\mathbf{1 2} \cdot \mathrm{HCl}$ and $(R)-\mathbf{1 0}+$ $\mathbf{1 4} \cdot \mathrm{HCl}$ systems (for both enantiomers of the amine components) relative to individual host or guest solutions were less than $0.02 \mathrm{ppm}$, and hence they cannot be used as indicators of complex formation. Furthermore, increasing of concentration (from 1 to $10 \mathrm{mM}$ ) of the individual hydrochloride salts in $\mathrm{CDCl}_{3}$ solutions leads to notable (ca $0.2 \mathrm{ppm}$ ) CSPs of $\mathrm{CH}$ - and Me 
protons for $\mathbf{1 2} \cdot \mathrm{HCl}$ and to negligible CSPs for $\mathbf{1 4} \cdot \mathrm{HCl}$. Thus, self-association of $\mathbf{1 2} \cdot \mathrm{HCl}$ molecules couldn't be excluded.

As a whole it is evident that ${ }^{1} \mathrm{H}$ CSs are not very useful instrument in the case of the hydrochloride salts, which is in complete agreement with early Cram et al. observations. ${ }^{4}$ Therefore to get insight of the phenomenon under question, an additional NMR method, namely DOSY, that provides diffusivity information, which is expressed in terms of self-diffusion coefficient D, was invoked. ${ }^{14}$ The simple physical meaning of the self-diffusion coefficient (the bigger the $\mathrm{D}$ the smaller the molecular system mass and vice versa) make for its wide use in compexation studies. ${ }^{15}$

Before to study binary systems, the self-associative properties of the individual components were analyzed (Table 1$)$. Because of almost no change of the $\mathrm{D}((R)-\mathbf{1 0})$ with concentration it is conceivable that no self-association of the host $(R)-\mathbf{1 0}$ in solution was occurred. On the contrary, decreasing of $\mathrm{D}$ with increasing of concentration proves that $14 \cdot \mathrm{HCl}$ and, in particular, $12 \cdot \mathrm{HCl}$ self-associates. Therefore self-diffusion coefficients of the guests $(\mathbf{1 2} \cdot \mathrm{HCl}$ and $\mathbf{1 4} \cdot \mathrm{HCl})$ in the binary systems $(\mathbf{1 0}+\mathbf{1 2} \cdot \mathrm{HCl})$ and $(\mathbf{1 0}+\mathbf{1 4} \cdot \mathrm{HCl})$ can hardly be used to monitor complexation between the components because the salts molecules are in fast exchange between free, selfaggregated and complexed states and its self-diffusion coefficients are weighted average. On the other hand almost no changes of $\mathrm{D}(\mathbf{1 0})$ in the studied systems (Table 1 ) indicates the absence of the more or less stable complexes formation between the host and these guests. This observation correlates well with the early Cram conclusion.

Table 1. Self-diffusion coefficient $\mathrm{D}\left(\times 10^{-9} \mathrm{~m}^{2} \cdot \mathrm{s}^{-1}\right)$ of individual crown $(R)-\mathbf{1 0}$ and alkylammonium hydrochloride salts $(\mathbf{1 2} \cdot \mathrm{HCl}, \mathbf{1 4} \cdot \mathrm{HCl})$ and their combinations, in $\mathrm{CDCl}_{3}$ at $\mathrm{T}=$ 298K. Standard deviations are less than $0.08 \times 10^{-9} \mathrm{~m}^{2} \cdot \mathrm{s}^{-1}$

\begin{tabular}{cccc}
\hline Sample & $c, \mathrm{mM}$ & $\begin{array}{c}\mathrm{D} \text { of crown } \\
\text { component }\end{array}$ & $\begin{array}{c}\text { D of amine } \\
\text { component }\end{array}$ \\
\hline$(R)-\mathbf{1 0}(\mathrm{M}=356)$ & 1 & 1.02 & \\
& 10 & 1.05 & 1.80 \\
$\mathbf{1 2} \cdot \mathrm{HCl}(\mathrm{M}=105)$ & 1 & & 0.66 \\
& 10 & & 0.81 \\
$\mathbf{1 4} \cdot \mathrm{HCl}(\mathrm{M}=122)$ & 1 & & 0.73 \\
$(R)-\mathbf{1 0}+(S)-1 \mathbf{2} \cdot \mathrm{HCl}$ & 10 & 0.92 & 0.68 \\
$(R)-\mathbf{1 0}+(R)-12 \cdot \mathrm{HCl}$ & 10 & 1.04 & 0.84 \\
$(R)-\mathbf{1 0}+(S)-1 \mathbf{H C l} \cdot \mathrm{HCl}$ & 10 & 1.03 & 0.94 \\
$(R)-\mathbf{1 0}+(R)-1 \mathbf{4} \cdot \mathrm{HCl}$ & 10 & 1.04 & 0.88 \\
\hline
\end{tabular}

In the cited work Cram et al. ${ }^{4}$ established that a precondition for observing diastereomeric complexes of crown ethers with amine salts was that $\mathrm{X}^{-}$of $\mathrm{RNH}_{3}{ }^{+} \mathrm{X}^{-}$be unable to hydrogen bond strongly with $\mathrm{NH}_{3}{ }^{+}$. They found that the $\mathrm{PF}_{6}^{-}, \mathrm{AsF}_{6}{ }^{-}$, and $\mathrm{SbF}_{6}{ }^{-}$ions fulfilled this 
condition, whereas $\mathrm{F}^{-}, \mathrm{Cl}^{-}, \mathrm{Br}^{-}, \mathrm{SCN}^{-}$, and $\mathrm{CCl}_{3} \mathrm{CO}_{2}{ }^{-}$did not. Choosing the $\mathrm{RNH}_{3}{ }^{+} \mathrm{PF}_{6}{ }^{-}$salts for our subsequent experiments we were guided by these recommendations. However salts with $\mathrm{PF}_{6}{ }^{-}$ anion are found to be non-soluble in $\mathrm{CDCl}_{3}$. Thus $\mathrm{D}$ of individual solutions of guests couldn't be determined. For this reason we have used ${ }^{1} \mathrm{H}$ NMR monitored liquid-liquid extraction for the binding properties evaluation in our concluding experiments.

Hexafluorophosphate salts of the amines 12-14 are not accessible as solids, so they were produced in $\mathrm{D}_{2} \mathrm{O}$ solution by ion exchange with excess of $\mathrm{LiPF}_{6}$ and the corresponding amine hydrochloride. The host 9-11 solution in $\mathrm{CDCl}_{3}(0.01 \mathrm{M}, 1$ equiv) was used to extract $\sim 3$ equiv of aqueous $\mathrm{RNH}_{3}{ }^{+} \mathrm{PF}_{6}{ }^{-}$salts. The $\mathrm{LiPF}_{6}$ not only served as the source of the extractible $\mathrm{PF}_{6}{ }^{-}$ anion, but $\mathrm{Li}^{+}, \mathrm{Cl}^{-}$, and excess $\mathrm{PF}_{6}{ }^{-}$ions "salted out" the organic guest complex from $\mathrm{D}_{2} \mathrm{O}$ layer to $\mathrm{CDCl}_{3}$ one. After extraction the organic phase was dried and analyzed. Typically, the relative concentrations of the enantiomeric guests in $\mathrm{CDCl}_{3}$ layer were determined from the ${ }^{1} \mathrm{H} \mathrm{NMR}$ spectra of their diastereomeric complexes. Analysis of intensities of guest's and host's signals in the ${ }^{1} \mathrm{H}$ NMR spectra of studied systems allows estimating the relative quantities of the corresponding substances (Table 2). The ${ }^{1} \mathrm{H}$ NMR chemical shifts of the $\mathrm{CH}_{3}, \mathrm{NC} * \mathrm{H}$ protons (chiral carbon is marked by asterisk) of the guests are represented in Table 2. ${ }^{1} \mathrm{H}$ NMR integral ratios of $\mathrm{CH}_{3}$ or $\mathrm{NC}^{*} \mathrm{H}$ protons to those of $\mathrm{Ar}(\mathrm{Ph})$ multiplets are listed in Table 2 as guest/host ratio. In the control experiments no traces of amines were detected in the $\mathrm{CDCl}_{3}$ phase free of the crown hosts.

Before proceeding to analyze the Table 2 data it must be noted that any enantiomer of methyl alaninate hexafluorophosphate $\mathbf{1 2} \cdot \mathrm{HPF}_{6}$ could not be traceable after extraction in the any of the studied host containing organic phase. In accordance with the Cram data, this phenomenon was associated with the great hydrophilicity of the alanine moiety. Thus, only enantiomeric $\alpha$ phenylethylammonium hexafluorophosphate $\mathbf{1 4}^{\mathrm{H}} \cdot \mathrm{HF}_{6}$ and methyl phenylglicinate hexafluorophosphate $\mathbf{1 3} \cdot \mathrm{HPF}_{6}$ were used for quantitative experiments.

As it follows from Table 2, runs 1-3, amine extraction is negligible in the case of 12membered crown 9 . The small cavity dimension is the obvious reason for the effect.

As the cavity dimension increases, as in the case of crowns $\mathbf{1 0}$ and 11a-b, so does the quantity of amine extracted into the chloroform phase increases too. This is evidenced by increase of the $\mathrm{G} / \mathrm{H}$ values in Table 2 . Some important tendencies could be traced from the runs 5-18. Firstly, the enantioselectivity of extraction is approximately inversely related to the quantity of extracted material. Thus maximum extraction potential demonstrates naphthyl containing crown 11b (runs 15-18). At the same time the enantioselectivity of these extractions is close to zero. Secondly, the effectiveness of the lariat ethers 10, having ortho-OMe substituent in the benzene ring, is approximately ten times larger in the amine guest transfer from water to organic phase than the same ability for lariat ethers 10a, with OMe group in para-position. 
Table 2. The guest/host ratio $\left(\mathrm{G} / \mathrm{H} ; \mathrm{CDCl}_{3}\right.$, r.t. $)$, observed in the extractions of $(S)$ - or $(R)-\alpha-$ phenylethylammonium hexafluorophosphate $\mathbf{1 4} \cdot \mathrm{HPF}_{6}$ and $(S)$ - or $(R)$-methyl phenylglicinate hexafluorophosphate $13 \cdot \mathrm{HPF}_{6}$ by crowns $\mathbf{9 - 1 1}$

\begin{tabular}{|c|c|c|c|c|c|c|}
\hline \multirow[t]{2}{*}{ Run } & \multirow[t]{2}{*}{ Host } & \multirow[t]{2}{*}{ Guest } & \multirow[t]{2}{*}{$\mathrm{G} / \mathrm{H}$} & \multirow[t]{2}{*}{$\mathrm{CRF}^{\mathrm{a}}$} & \multicolumn{2}{|r|}{$\delta$} \\
\hline & & & & & $\mathrm{CH}_{3}$ & $\mathrm{C}^{*} \mathrm{H}$ \\
\hline 1 & $(R)-9$ & $(S)-\mathbf{1 3} \cdot \mathrm{HPF}_{6}$ & 0.0 & - & & \\
\hline 2 & & $(R)-13 \cdot \mathrm{HPF}_{6}$ & 0.0 & - & & \\
\hline 3 & & $(S)-\mathbf{1 4} \cdot \mathrm{HPF}_{6}$ & 0.0 & - & & \\
\hline 4 & & $(R)-\mathbf{1 4} \cdot \mathrm{HPF}_{6}$ & $t r^{\mathrm{c}}$ & - & $1.67^{b}$ & 4.59 \\
\hline 5 & $(S)-\mathbf{1 0}$ & $(S)-\mathbf{1 4} \cdot \mathrm{HPF}_{6}$ & 0.48 & $\sim 1.2$ & $1.62^{\mathrm{b}}$ & 4.45 \\
\hline 6 & & $(R)-\mathbf{1 4} \cdot \mathrm{HPF}_{6}$ & 0.56 & & $1.63^{\mathrm{b}}$ & 4.42 \\
\hline 7 & & $(S)-13 \cdot \mathrm{HPF}_{6}$ & 0.25 & $\sim 0.8$ & & 5.12 \\
\hline 8 & & $(R)-\mathbf{1 3} \cdot \mathrm{HPF}_{6}$ & 0.19 & & & 5.05 \\
\hline 9 & $(S)-\mathbf{1 0 a}$ & $(S)-\mathbf{1 4} \cdot \mathrm{HPF}_{6}$ & 0.06 & - & $1.69^{b}$ & 4.49 \\
\hline 10 & & $(R)-\mathbf{1 4} \cdot \mathrm{HPF}_{6}$ & $t r^{\mathrm{c}}$ & & $1.69^{b}$ & 4.49 \\
\hline 11 & $(R)-\mathbf{1 1 a}$ & $(S)-\mathbf{1 4} \cdot \mathrm{HPF}_{6}$ & 0.32 & 0.9 & $1.51^{\mathrm{b}}$ & \\
\hline 12 & & $(R)-\mathbf{1 4} \cdot \mathrm{HPF}_{6}$ & 0.29 & & $1.51^{\mathrm{b}}$ & \\
\hline 13 & & $(S)-\mathbf{1 3} \cdot \mathrm{HPF}_{6}$ & 0.39 & 0.9 & 3.56 & 4.86 \\
\hline 14 & & $(R)-\mathbf{1 3} \cdot \mathrm{HPF}_{6}$ & 0.35 & & 3.52 & 4.80 \\
\hline 15 & $(S)-\mathbf{1 1 b}$ & $(S)-\mathbf{1 4} \cdot \mathrm{HPF}_{6}$ & 0.67 & $\sim 1$ & $1.47^{\mathrm{b}}$ & 4.31 \\
\hline 16 & & $(R)-\mathbf{1 4} \cdot \mathrm{HPF}_{6}$ & 0.64 & & $1.49^{b}$ & 4.32 \\
\hline 17 & & $(S)-\mathbf{1 3} \cdot \mathrm{HPF}_{6}$ & 0.54 & 1.1 & 3.48 & 4.80 \\
\hline 18 & & $(R)-\mathbf{1 3} \cdot \mathrm{HPF}_{6}$ & 0.62 & & 3.50 & 4.86 \\
\hline 19 & $(a S, S)-11 c$ & $(S)-\mathbf{1 4} \cdot \mathrm{HPF}_{6}$ & 0.22 & high & $1.44^{\mathrm{b}}$ & 4.33 \\
\hline 20 & & $(R)-\mathbf{1 4} \cdot \mathrm{HPF}_{6}$ & 0.0 & & & \\
\hline 21 & & $(S)-\mathbf{1 3} \cdot \mathrm{HPF}_{6}$ & 0.07 & 2.5 & & 4.98 \\
\hline 22 & & $(R)-13 \cdot \mathrm{HPF}_{6}$ & 0.17 & & & 5.05 \\
\hline
\end{tabular}

${ }^{\mathrm{a}} \mathrm{CRF}$ - chiral recognition factor, $[\mathrm{G}]_{\mathrm{R}} /[\mathrm{G}]_{\mathrm{S}}$, where $[\mathrm{G}]_{\mathrm{R}}$ and $[\mathrm{G}]_{\mathrm{S}}$ is the relative amounts of $R$ - or $S$-guest extracted into $\mathrm{CDCl}_{3}$ phase. ${ }^{\mathrm{b}} \mathrm{d}, J=7 \mathrm{~Hz}$. ${ }^{\mathrm{c}}$ traces.

An introduction of the BINOL chiral moiety instead of catechol fragment in the structure of crown 11a not only enlarges the macrocycle cavity in the case of 11c, but disturbs it in the asymmetric way. As a result, the general complexation ability for the crowns 11c decreases, yet the enantioselectivity of this complexation increases. Thus, during amine salt extraction by crown host $(a S, S)-\mathbf{1 1 c}$ about $22 \%$ of the $(S)-\mathbf{1 4} \cdot \mathrm{HPF}_{6}$ finds its way into chloroform phase, whereas $(R)-\mathbf{1 4} \cdot \mathrm{HPF}_{6}$ does not (runs 19-20).

As one could see, for the $\mathbf{1 1} \mathbf{c}+\mathbf{1 3} \cdot \mathrm{HPF}_{6}$ system (runs 21-22) there is a noticeable difference in extraction for different enantiomers, too. That's why this system was used for quantitative extraction of rac-13. $\mathrm{HPF}_{6} \mathrm{D}_{2} \mathrm{O}$ solutions with $\mathrm{CDCl}_{3}$ solutions of optically pure host $(a S, S)-\mathbf{1 1 c}$. 
During this experiment the layers were equilibrated, the neutral guest was isolated from the complex transferring into organic layer, and the optical rotations of the individual $\mathbf{1 3}$ were taken. The isolated by this means phenylglycine methyl ester has had an optical purity of $22 \%$, enriched in the $(R)$-enantiomer.

\section{Conclusions}

Summering up, we could say that the conglomerate nature and the developed on this basis the effective procedure of direct resolution of guaifenesin $\mathbf{1}$ enable an easy access to the family of enantiomeric lariat crown ethers 9-11. These crowns show no evidence of host/guest association with hydrochloride salts of chiral amines. In the same time these crowns show a capacity for host/guest binding of some ammonium hexafluorophosphate salts which is embodied in the extraction of the guest molecules from aqueous to organic phase. The effectiveness of the lariat ethers 10, having ortho-OMe substituent in the benzene ring, is larger than the same ability for ethers 10a, with OMe group in para-position. Moderate enantiomeric recognition of organic ammonium hexafluorophosphates was achieved with lariat ethers 11c. By and large, the enantioselectivity of extraction is approximately inversely related to the quantity of extracted material.

\section{Experimental Section}

General. The NMR spectra were recorded on a Bruker Avance-600 spectrometer $(600.13 \mathrm{MHz}$ for ${ }^{1} \mathrm{H} ; 150.864 \mathrm{MHz}$ for ${ }^{13} \mathrm{C}$ ) in $\mathrm{CDCl}_{3}$ with TMS or the signals of the solvent as the internal standard. Optical rotations were measured on a Perkin-Elmer model 341 polarimeter (concentration $c$ is given as $\mathrm{g} / 100 \mathrm{~mL}$ ). Melting points were determined using a Boëtius apparatus and are uncorrected. The UV-Vis spectra were measured by a Perkin Elmer Lambda 35UV spectrometer. HPLC analyses were performed on a Shimadzu LC-20AD system controller, and UV monitor $275 \mathrm{~nm}$ was used as a detector. As a rule, the column used, from Daicel, Inc., was Chiralcel OD $(0.46 \times 25 \mathrm{~cm})$; column temperature $40{ }^{\circ} \mathrm{C}$; flow rate: $0.4 \mathrm{ml} / \mathrm{min}$. Mass spectra EI were recorded on a mass-spectrometer MAT-212, mass spectra MALDI-TOF were recorded on a mass-spectrometer ULTRAFLEX III.

\section{Synthesis}

4-Dimethylaminopyridine, 2-(2-chloroethoxy)ethanol 2,3-dihydroxynaphtalene, lithium hexafluorophosphate, D-alanine methyl ester hydrochloride were purchased from Alfa Aesar. LAlanine methyl ester hydrochloride was purchased from Fluka. D-Alanine methyl ester hydrochloride was purchased from Aldrich. $(R)$ - and $(S)$ - $\alpha$-phenyl ethylamine, D(-)- and L(+)alpha-phenylglycine, were purchased from Acros Organics. Racemic, D- and L-methyl 
phenylglicinate hydrochloride were prepared according to literature procedure. ${ }^{4}$ The hydrochloride salts of $(R)$ - and $(S)$ - $\alpha$-phenyl ethylamine were prepared by bubbling $\mathrm{HCl}$ gas into solutions of the amine in dry ether. All reactions were carried out in a dry argon atmosphere. All organic solutions and reagents were purified and dried, following standard procedures.

Racemic guaifenesin, 3-(2-methoxyphenoxy)propane-1,2-diol, rac-1 is commercially available (Alfa Aesar, A16827); $(R)$ - and (S)-3-(2-methoxyphenoxy)-propane-1,2-diol were prepared from racemate by entrainment resolution method according to previously described protocol. ${ }^{10}$

\section{Resolution of racemic 3-(2-methoxyphenoxy)-1,2-propanediol (Guaifenesin, rac-1) by preferential crystallization (entrainment)}

Racemic guaifenesin rac-1 (90.46 g) and (R)-1 (9.54 g) was dissolved in $800 \mathrm{ml}$ of water at 42$45{ }^{\circ} \mathrm{C}$. The solution was cooled to $23{ }^{\circ} \mathrm{C}$ and seeded with finely pulverized $(R)-\mathbf{1}(0.25 \mathrm{~g})$. After stirring the mixture for $100 \mathrm{~min}$ at $22 \pm 0.5^{\circ} \mathrm{C}$, precipitated $(R)-1$ was collected by filtration $(21.26 \mathrm{~g}, 91 \% \mathrm{ee})$. The extra portion of rac-1 (21.01 g) was then dissolved in the mother liquor at $42{ }^{\circ} \mathrm{C}$; the resulting solution was cooled to $23{ }^{\circ} \mathrm{C}$. After the addition of $(S)-\mathbf{1}(0.25 \mathrm{~g})$ as seed crystals to the solution, and stirring the mixture for $110 \mathrm{~min}$ at $22 \pm 0.5{ }^{\circ} \mathrm{C},(S)-1(19.11 \mathrm{~g}, 99 \%$ ee) was collected by filtration. Further resolution was carried out at $22 \pm 0.5{ }^{\circ} \mathrm{C}$ by adding amended amounts of $\mathrm{rac}-\mathbf{1}$ to the filtrate in a manner similar to that described above. After second cycle, $17.53 \mathrm{~g}$ of $(R)-\mathbf{1}$ ( > $99 \%$ ee) and $17.22 \mathrm{~g}$ of $(S)-\mathbf{1}(84 \%$ ee) were collected. After third cycle, $19.68 \mathrm{~g}$ of $(R)-\mathbf{1}(87 \%$ ee) and $22.60 \mathrm{~g}$ of $(S)-\mathbf{1}(89 \%$ ee) were collected. A high degree of enantiomeric purity of collected diols can be achieved by simple recrystallization.

(S)-3-(2-Methoxyphenoxy)propane-1,2-diol, (S)-1. Mp 97-99 ${ }^{\circ} \mathrm{C} ;[\alpha]_{\mathrm{D}}{ }^{20}=+9.5$ (c 1.0, $\mathrm{MeOH}$ ); $99.9 \%$ ee (chiral HPLC analysis: Chiralcel OD; n-hexane/isopropanol/Et ${ }_{2} \mathrm{NH}=$ 80:20:0.1; flow rate $1.0 \mathrm{~mL} / \mathrm{min} ; t_{\mathrm{R}}=17.4 \mathrm{~min}$ ).

(R)-3-(2-Methoxyphenoxy)propane-1,2-diol, (R)-1. Mp 97-99 ${ }^{\circ} \mathrm{C} ;[\alpha]_{\mathrm{D}}{ }^{20}=-9.4$ (c 1.0, $\mathrm{MeOH}$ ); $99.5 \%$ ee (chiral HPLC analysis: Chiralcel OD; n-hexane/isopropanol/Et ${ }_{2} \mathrm{NH}=$ 80:20:0.1; flow rate $\left.1.0 \mathrm{~mL} / \mathrm{min} ; t_{\mathrm{R}}=9.9 \mathrm{~min}\right)$.

(S)-3-(4-Methoxyphenoxy)propane-1,2-diol, $(\boldsymbol{S})$-1a was prepared by analogy with a published procedure $^{16}$ from 4-methoxyphenol and (S)-3-chloropropane-1,2-diol. Mp 79-81 ${ }^{\circ} \mathrm{C}$ (nhexane/benzene) (lit. ${ }^{17} \mathrm{mp} \mathrm{80-82}{ }^{\circ} \mathrm{C}$; lit. $\left.{ }^{18} \mathrm{mp} 80{ }^{\circ} \mathrm{C}\right) ;[\alpha]_{\mathrm{D}}{ }^{20}=+7.5(c$ 0.6, EtOH); $95 \%$ ee [chiral HPLC analysis; Daicel Chiralpak AD-RH $(0.46 \times 15 \mathrm{~cm})$ column; column temperature 27 ${ }^{\circ} \mathrm{C}$; eluent: isopropanol $/$ water $=1: 3 ; t_{\mathrm{R}}=18.5 \mathrm{~min}$ (minor), $t_{\mathrm{R}}=21.8 \mathrm{~min}$ (major)]; $\left\{\right.$ lit. ${ }^{17}[\alpha]_{\mathrm{D}}{ }^{20}=$ $+7.3(c 1.28, \mathrm{EtOH}), 88.7 \%$ ee; lit. $^{19}[\alpha]_{\mathrm{D}}{ }^{20}=+7.9$ (c 1.0, $\left.\mathrm{EtOH}\right), 96 \%$ ee $\}$.

1-(Tetrahydropyranyloxy)-2-[(p-tolylsulfonyl)-oxy]ethane (4) was prepared by analogy with a published method ${ }^{12}$ from tosyl chloride $(46.0 \mathrm{~g}, 0.24 \mathrm{~mol})$ and 2-(tetrahydropyranyloxy)ethanol (35.28 g, $0.24 \mathrm{~mol})$. Yield $71.0 \mathrm{~g}(98 \%)$.

(S)-4-(2-Methoxyphenoxy)methyl-3,6-dioxa-1,8-octanediol, $(S)$-3 was prepared by analogy with a published method. ${ }^{12}$ To a suspension of $\mathrm{NaH}(1.68 \mathrm{~g}, 70 \mathrm{mmol})$ in $20 \mathrm{~mL}$ of THF was added a solution of (S)-3-(2-methoxyphenoxy)propane-1,2-diol, $(S)$-1 (4.95 g, $25 \mathrm{mmol})$ in 75 $\mathrm{mL}$ of THF at $0{ }^{\circ} \mathrm{C}$. The reaction mixture was stirred for $15 \mathrm{~min}$ at $0{ }^{\circ} \mathrm{C}$ and then $1 \mathrm{~h}$ at room 
temperature and refluxed for $2 \mathrm{~h}$. Then a solution of 1-(tetrahydro-pyranyloxy)-2-[(ptolylsulfonyl)oxy]ethane $4(15.0 \mathrm{~g}, 50 \mathrm{mmol})$ in $70 \mathrm{~mL}$ of THF was slowly dropwise added to the refluxing solution for $3 \mathrm{~h}$. When the addition was completed, refluxing was continued for 50 h. After addition of water $(300 \mathrm{~mL})$, the mixture was extracted with $\mathrm{Et}_{2} \mathrm{O}(3 \times 150 \mathrm{~mL})$. The combined ether layers were washed with brine, dried on $\mathrm{MgSO}_{4}$ and concentrated under reduced pressure. The crude product was dissolved in $45 \mathrm{~mL}$ of methanol and acidified with $1 \mathrm{M} \mathrm{HCl}$ before $\mathrm{pH}$ 2. The reaction mixture was stirred for $8 \mathrm{~h}$ and basified with $\mathrm{NaHCO}_{3}$. The water layer was extracted with $\mathrm{CH}_{2} \mathrm{Cl}_{2}(3 \times 150 \mathrm{~mL})$. The combined organic layers were dried on $\mathrm{MgSO}_{4}$ and concentrated under reduced pressure. The crude product was purified by column chromatography (silica gel, EtOAc/light petroleum/EtOH $=14: 7: 2$ ) to give $1.93 \mathrm{~g}(27 \%$ ) of pure $(S)-3$ as pale yellow oil; $[\alpha]_{\mathrm{D}}{ }^{20}=-2.5\left(c\right.$ 2.0, $\left.\mathrm{CHCl}_{3}\right) ; 99.0 \%$ ee [chiral HPLC analysis: Chiralcel OD; n-hexane/isopropanol $=9: 1$; flow rate: $1 \mathrm{ml} / \mathrm{min} ; t_{\mathrm{R}}=23.2 \mathrm{~min}$ (minor), $t_{\mathrm{R}}=28.3 \mathrm{~min}$ (major)]. ${ }^{1} \mathrm{H}$ NMR $\delta$ : 2.48 (br.s, 1H, OH), 3.14 (br.s, 1H, OH), 3.61-3.63 (m, 2H), 3.67 (dd, $J=$ $10.5,5.9 \mathrm{~Hz}, 1 \mathrm{H}), 3.71-3.79(\mathrm{~m}, 7 \mathrm{H}), 3.84\left(\mathrm{~s}, \mathrm{OCH}_{3}\right), 3.99-4.02(\mathrm{~m}, 1 \mathrm{H}, \mathrm{CH}), 4.06(\mathrm{dd}, J=9.9$, $6.6 \mathrm{~Hz}, 1 \mathrm{H}), 4.10(\mathrm{dd}, J=9.9,4.6 \mathrm{~Hz}, 1 \mathrm{H}), 6.88-6.94(\mathrm{~m}, 4 \mathrm{H}, \mathrm{Ar})$. EI mass-spectrum [m/z(I\%)] $\mathrm{C}_{14} \mathrm{H}_{22} \mathrm{O}_{6}$ : 287(10), 286(53), 149(17), 124(100), 122(7), 109(11), 101(37), 87(21), 77(9), 75(18), 69(6), 61(11), 59(6), 57(26), 45(79), 43(13), 41(11), 31(11).

(R)-4-(2-Methoxyphenoxy)methyl-3,6-dioxa-1,8-octanediol, $\quad(\boldsymbol{R})-3 \quad$ was synthesized analogously from the $(R)-3-(2-m e t h o x y p h e n o x y)$ propane-1,2-diol, $(R)-\mathbf{1} ;[\alpha]_{\mathrm{D}}{ }^{20}=+3.0(c 1.1$, $\left.\mathrm{CHCl}_{3}\right),[\alpha]_{\mathrm{D}}^{20}=-2.5(c$ 1.7, MeOH); $99.2 \%$ ee [chiral HPLC analysis: Chiralcel OD; $\mathrm{n}-$ hexane/isopropanol = 9:1; flow rate: $1 \mathrm{ml} / \mathrm{min} ; t_{\mathrm{R}}=24.1 \mathrm{~min}$ (major), $\left(t_{\mathrm{R}}=29.6 \mathrm{~min}\right.$ (minor)].

2,2'-Dihydroxy-1,1'-binaphthyl, 2c. Racemic 2c was synthesized by a known procedure ${ }^{20}$ by oxidation of $\beta$-naphthol ( $30.0 \mathrm{~g}, 0.2 \mathrm{~mol})$ with ferric chloride $(56.26 \mathrm{~g}, 0.2 \mathrm{~mol})$. The yield was $28.6 \mathrm{~g}(88 \%)$. Resolution of rac-2c was carried out, as described previously ${ }^{21}$ based on different solubility of its complexes with $(R, R)-1,2$-diaminocyclohexane in toluene; $(\mathrm{a} R)-2 \mathrm{c}:[\alpha]_{\mathrm{D}}{ }^{20}=+$ 34.3 (c 1.0, THF); mp 208-210 ${ }^{\circ} \mathrm{C},\left\{\right.$ lit. $^{22}[\alpha]_{\mathrm{D}}{ }^{20}=+34.3$ (c 1.0, THF); mp 207.5-208.5 $\left.{ }^{\circ} \mathrm{C}\right\}$. $(\mathrm{aS})-2 \mathrm{c}:[\alpha]_{\mathrm{D}}{ }^{20}=-33.8$ (c 1.0, THF); mp 208-210 ${ }^{\circ} \mathrm{C},\left\{\right.$ lit. $^{22}[\alpha]_{\mathrm{D}}{ }^{20}=-33.3$ (c 1.0, THF); mp 207-208 $\left.{ }^{\circ} \mathrm{C}\right\}$.

1,2-Bis-(2-hydroxyethoxy)benzene (5a) was prepared according to the known procedure ${ }^{8 \mathrm{a}}$ from catechol (11 g, $100 \mathrm{mmol})$, diethylamine hydrochloride (as a catalyst) and ethylene oxide (9.8 $\mathrm{ml}, 200 \mathrm{mmol})$. The yield was $17.9 \mathrm{~g}, 91 \%$; mp 81-83 ${ }^{\circ} \mathrm{C}$ (EtOH/ether 1:1) (lit. $\left.{ }^{8 \mathrm{a}} \mathrm{mp} \mathrm{81-83}{ }^{\circ} \mathrm{C}\right)$.

2,3-Bis-(2-hydroxyethoxy)naphthalene (5b) was synthesized according to above described method by using 2,3-dihydroxynaphthalene $\mathbf{2 b}(1.6 \mathrm{~g}, 10 \mathrm{mmol})$, piperidine hydrochloride (as catalyst) and ethylene oxide $(0.98 \mathrm{~mL}, 20 \mathrm{mmol})$. The yield was $2.21 \mathrm{~g}(89 \%)$; mp 146-147 ${ }^{\circ} \mathrm{C}$ (lit. ${ }^{8 \mathrm{a}} \mathrm{mp} 146-147^{\circ} \mathrm{C}$ ).

(S)-2,2'-Bis(2-hydroxyethoxy)-1,1'-binaphthyl, (aS)-5c was prepared according to literature procedure $^{13}$ from $(\mathrm{aS})-2 \mathrm{c}(8.62 \mathrm{~g}, 30.1 \mathrm{mmol}), 2$-chloroethanol $(8.0 \mathrm{~mL}, 119 \mathrm{mmol})$ and $\mathrm{K}_{2} \mathrm{CO}_{3}$ $(16.62 \mathrm{~g}, 120 \mathrm{mmol})$ to give $10.21 \mathrm{~g}(91 \%)$ of $(\mathrm{aS})-5 \mathrm{c} ; \mathrm{mp} 130-134{ }^{\circ} \mathrm{C} ;[\alpha]_{\mathrm{D}}{ }^{20}=+26.4(c 0.8$, THF); [lit. ${ }^{13} \mathrm{mp} 131-134{ }^{\circ} \mathrm{C} ;[\alpha]_{578}{ }^{20}=+25.1$ ( $c 0.958$, THF)]. 
(R)-2,2'-Bis(2-hydroxyethoxy)-1,1'-binaphthyl, (aR)-5c was prepared from (aR)-2c in a manner similar to that described for the preparation of $(\mathrm{a} S)-5 \mathbf{c} ; \mathrm{mp} 131-134{ }^{\circ} \mathrm{C} ;[\alpha]_{\mathrm{D}}{ }^{20}=-26.4(c$ 0.8, THF); [lit. ${ }^{13} \mathrm{mp} 130-134{ }^{\circ} \mathrm{C} ;[\alpha]_{578}{ }^{20}=-26.4$ (c 0.76, THF)].

1,2-Bis-[2-(p-tolylsulfonyl)ethoxy]benzene (6a) was synthesized according to the procedure ${ }^{8 \mathrm{a}}$ from 1,2-bis-(2-hydroxyethoxy)benzene 5a (9 $\mathrm{g}, 45.5 \mathrm{mmol})$, pyridine $(40 \mathrm{~mL})$ and $p$ toluenesulfonylchloride $(17 \mathrm{~g}, 89.3 \mathrm{mmol})$ at $-10{ }^{\circ} \mathrm{C}$ to give $21.9 \mathrm{~g}(96 \%)$; mp 95-96 ${ }^{\circ} \mathrm{C}$ (MeOH); (lit. $\left.{ }^{8 \mathrm{a}} \mathrm{mp} 95-95.5{ }^{\circ} \mathrm{C}\right) .{ }^{1} \mathrm{H}$ NMR $\delta: 2.45$ (s, 6H, $\left.\mathrm{CH}_{3}\right), 4.17$ (t, $\left.J=4.6 \mathrm{~Hz}, 4 \mathrm{H}\right), 4.34$ (t, $J$ $=4.6 \mathrm{~Hz}, 4 \mathrm{H}), 6.82(\mathrm{dd}, J=5.9,3.4 \mathrm{~Hz}, 2 \mathrm{H}), 6.91(\mathrm{dd}, J=5.9,3.3 \mathrm{~Hz}, 2 \mathrm{H}), 7.34(\mathrm{~d}, J=8.1 \mathrm{~Hz}$, $4 \mathrm{H}), 7.81(\mathrm{~d}, J=8.1 \mathrm{~Hz}, 4 \mathrm{H})$.

2,3-Bis-[2-(p-tolylsulfonyl)ethoxy]naphthalene (6b) was synthesized according to the procedure $^{8 \mathrm{a}}$ from $\mathbf{5 b}(2.20 \mathrm{~g}, 8.9 \mathrm{mmol}), p$-toluenesulfonylchloride $(3.38 \mathrm{~g}, 17.7 \mathrm{mmol})$ and pyridine (16 mL) to give $3.92 \mathrm{~g}(81 \%)$; mp $111-112^{\circ} \mathrm{C}$ [lit. ${ }^{8 \mathrm{a}} \mathrm{mp} 111-112{ }^{\circ} \mathrm{C}$ ] ${ }^{1} \mathrm{H}$ NMR $\delta: 2.41$ $\left(\mathrm{s}, 6 \mathrm{H}, \mathrm{CH}_{3}\right), 4.28(\mathrm{dd}, J=5.2,4.3 \mathrm{~Hz}, 4 \mathrm{H}), 4.43(\mathrm{dd}, J=5.2,4.3 \mathrm{~Hz}, 4 \mathrm{H}), 7.06(\mathrm{~s}, 2 \mathrm{H}), 7.31(\mathrm{~d}$, $J=8.1 \mathrm{~Hz}, 4 \mathrm{H}), 7.36(\mathrm{dd}, J=6.2,2.9 \mathrm{~Hz}, 2 \mathrm{H}), 7.63(\mathrm{dd}, J=6.2,3.3 \mathrm{~Hz}, 2 \mathrm{H}), 7.82(\mathrm{~d}, J=8.1$ $\mathrm{Hz}, 4 \mathrm{H})$.

(S)-2,2'-Bis(2-(p-tolylsulfonyl)ethoxy)-1,1'-binaphthyl, (aS)-6c was prepared by analogy with a published method. ${ }^{13}$ To a solution of $(\mathrm{aS})-5 \mathrm{c}(5.10 \mathrm{~g}, 13.6 \mathrm{mmol})$, triethylamine $(4.1 \mathrm{~mL}, 30$ mmol) and 4-(N,N-dimethylamino)pyridine (DMAP) $\left(55 \mathrm{mg}, 0.87 \mathrm{mmol}\right.$ ) in $300 \mathrm{~mL}$ of $\mathrm{CH}_{2} \mathrm{Cl}_{2}$ was added $p$-toluenesulfonylchloride $(5.68 \mathrm{~g}, 29.8 \mathrm{mmol})$ at $0{ }^{\circ} \mathrm{C}$ for $15 \mathrm{~min}$. The reaction mixture was stirred at room temperature for $20 \mathrm{~h}$ and subsequently washed with water $(5 \times 60$ $\mathrm{mL}$ ). The organic layer was dried on $\mathrm{MgSO}_{4}$ and concentrated under reduced pressure to give $8.93 \mathrm{~g}(96 \%)$ of $(\mathrm{aS})-\mathbf{6 c}$ as white crystals; mp $148-150{ }^{\circ} \mathrm{C}$ (toluene/n-hexane $\left.=8: 2\right) ;[\alpha]_{\mathrm{D}}{ }^{20}=$ $+80.4\left(c\right.$ 1.0, $\left.\mathrm{CH}_{2} \mathrm{Cl}_{2}\right)$; [lit. $\left.{ }^{23} \mathrm{mp} 144-146{ }^{\circ} \mathrm{C} ;[\alpha]_{\mathrm{D}}{ }^{20}=+80.4\left(c 1, \mathrm{CH}_{2} \mathrm{Cl}_{2}\right)\right] .{ }^{1} \mathrm{H} \mathrm{NMR} \delta: 2.37(\mathrm{~s}$, $6 \mathrm{H}), 3.92-3.96(\mathrm{~m}, 2 \mathrm{H}), 4.06-4.09(\mathrm{~m}, 2 \mathrm{H}), 4.16-4.19(\mathrm{~m}, 2 \mathrm{H}), 4.26-4.47(\mathrm{~m}, 2 \mathrm{H}), 7.04(\mathrm{~d}, J=$ $8.1 \mathrm{~Hz}, 4 \mathrm{H}), 7.11(\mathrm{~d}, J=8.4 \mathrm{~Hz}, 2 \mathrm{H}), 7.24(\mathrm{dd}, J=8.1,7.1 \mathrm{~Hz}, 2 \mathrm{H}), 7.39(\mathrm{~m}, J=8.4,2.6,3.7$ $\mathrm{Hz}, 8 \mathrm{H}), 7.91$ (d, $J=8.1 \mathrm{~Hz}, 2 \mathrm{H}), 7.99$ (d, $J=9.1 \mathrm{~Hz}, 2 \mathrm{H})$.

$(R)-2,2^{\prime}-\operatorname{Bis}(2-(p$-tolylsulfonyl)ethoxy)-1,1'binaphthyl, (aR)-6c was prepared from (aR)-5c in a manner similar to that described for the preparation of $(\mathrm{a} S)-\mathbf{6 c}$; mp $148-150{ }^{\circ} \mathrm{C}$ (toluene/ $\mathrm{n}$ hexane $=8: 2) ;[\alpha]_{\mathrm{D}}{ }^{20}=-80.3\left(c 1.0, \mathrm{CH}_{2} \mathrm{Cl}_{2}\right)$.

(R)-2,2'-Bis(5-hydroxy-3-oxa-1-pentiloxy)-1,1'-binaphthyl, (aR)-7c. The compound was prepared by analogy with a published method. ${ }^{13}$ A mixture of $(\mathrm{a} R)-2 \mathrm{c}(9.70 \mathrm{~g}, 33.9 \mathrm{mmol}), 2-(2-$ chloroethoxy)ethanol $(16.82 \mathrm{~g}, 14.2 \mathrm{~mL}, 135 \mathrm{mmol})$ and $\mathrm{K}_{2} \mathrm{CO}_{3}(19.0 \mathrm{~g}, 137 \mathrm{mmol})$ in $170 \mathrm{~mL}$ of DMF was stirred at $110{ }^{\circ} \mathrm{C}$ for $20 \mathrm{~h}$. The reaction mixture was filtrated and concentrated under reduced pressure. The residue was taken up in $\mathrm{CH}_{2} \mathrm{Cl}_{2}(150 \mathrm{~mL})$ and washed with water $(5 \mathrm{x} 60$ $\mathrm{mL})$ and $2 \mathrm{M} \mathrm{NaOH}(100 \mathrm{~mL})$. The organic layer was dried on $\mathrm{MgSO}_{4}$ and concentrated under reduced pressure to give a viscous oil. The crude product was purified by column chromatography (silica gel, EtOAc/n-hexane $=3: 6$ and 9:1) to give $(\mathrm{a} R)-7 \mathrm{c}(14.42 \mathrm{~g}, 92 \%)$ as a yellow oil; $[\alpha]_{\mathrm{D}}{ }^{20}=+29.1\left(c\right.$ 1.5, THF). ${ }^{1} \mathrm{H}$ NMR $\delta: 3.15-3.21(\mathrm{~m}, 4 \mathrm{H}), 3.37-3.44(\mathrm{~m}, 6 \mathrm{H}), 3.49$ $3.52(\mathrm{~m}, 2 \mathrm{H}), 4.0-4.03(\mathrm{~m}, 2 \mathrm{H}), 4.14-4.17(\mathrm{~m}, 2 \mathrm{H}), 7.16(\mathrm{~d}, J=11.6 \mathrm{~Hz}, 2 \mathrm{H}), 7.22(\mathrm{dd}, J=8.1$, $8.5,2 \mathrm{H}), 7.34(\mathrm{dd}, J=8.1,7.7 \mathrm{~Hz}, 2 \mathrm{H}), 7.44(\mathrm{~d}, J=9.0 \mathrm{~Hz}, 2 \mathrm{H}), 7.88(\mathrm{~d}, J=8.1 \mathrm{~Hz}, 2 \mathrm{H}), 7.96$ 
$(\mathrm{d}, J=9.0 \mathrm{~Hz}, 2 \mathrm{H})$. MALDI mass-spectra $\mathrm{C}_{28} \mathrm{H}_{30} \mathrm{O}_{6}:[\mathrm{M}]^{+}$462.58, $[\mathrm{MH}]^{+} 463.57,[\mathrm{M}+\mathrm{Na}]^{+}$ 485.58, $[\mathrm{M}+\mathrm{K}]^{+} 501.68$.

2,3-Bis(5-tosyloxy-3-oxa-1-pentyloxy)naphthalene (8b) was synthesized as described below for $8 \mathbf{c}$ by using $7 \mathbf{b}^{24}$ (3.64 g, $9.35 \mathrm{mmol}$, mp 55-56 $\left.{ }^{\circ} \mathrm{C}\right), \mathrm{Et}_{3} \mathrm{~N}$ (2.08 g, $\left.20.6 \mathrm{mmol}\right)$, DMAP (37.4 $\mathrm{mg}, 0.3 \mathrm{mmol})$ and $p$-toluenesulfonylchloride $(3.92 \mathrm{~g}, 20.6 \mathrm{mmol})$ to give $5.26 \mathrm{~g}(75.4 \%$, viscous oil).

(R)-2,2'-Bis(5-tosyloxy-3-oxa-1-pentyloxy)-1,1'-binaphthyl, (aR)-8c was prepared by analogy with a published method. ${ }^{13}$ To a solution of $(\mathrm{a} R)-7 \mathrm{c}(13.42 \mathrm{~g}, 29 \mathrm{mmol}), \mathrm{Et}_{3} \mathrm{~N}(8.7 \mathrm{~mL}, 63.8$ mmol $)$ and DMAP $(0.145 \mathrm{~g}, 1.16 \mathrm{mmol})$ in $\mathrm{CH}_{2} \mathrm{Cl}_{2}(300 \mathrm{~mL})$ was added $p$ toluenesulfonylchloride $(12.29 \mathrm{~g}, 64.16 \mathrm{mmol})$ at $0{ }^{\circ} \mathrm{C}$ for $15 \mathrm{~min}$. The reaction mixture was stirred at room temperature for $20 \mathrm{~h}$ and subsequently washed with water $(5 \mathrm{x} 60 \mathrm{~mL})$. The organic layer was dried on $\mathrm{MgSO}_{4}$ and concentrated under reduced pressure. The crude product was purified by column chromatography (silica gel, EtOAc/n-hexane $=3: 6$ and 9:1) that obtained $(\mathrm{a} R)-8 \mathrm{c}(20.79 \mathrm{~g}, 93 \%)$ as an orange viscous oil; $[\alpha]_{\mathrm{D}}{ }^{20}=+31.1$ (c 1.0, THF); $\left\{\right.$ lit. $^{25}[\alpha]_{578}{ }^{25}=$ +31.0 (c 1.0, THF)]. ${ }^{1} \mathrm{H}$ NMR $\delta: 2.43(\mathrm{~s}, 6 \mathrm{H}), 2.95-2.98(\mathrm{~m}, 2 \mathrm{H}), 3.01-3.05(\mathrm{~m}, 2 \mathrm{H}), 3.38(\mathrm{t}, J=$ $4.7 \mathrm{~Hz}, 4 \mathrm{H}), 3.68(\mathrm{t}, J=4.7 \mathrm{~Hz}, 4 \mathrm{H}), 3.98-4.06(\mathrm{~m}, 4 \mathrm{H}), 7.14(\mathrm{~d}, J=8.2 \mathrm{~Hz}, 2 \mathrm{H}), 7.20(\mathrm{dd}, J=$ 8.2, 7.0 Hz, 2H), 7.27-7.32 (m, 6H), $7.37(\mathrm{~d}, J=8.8 \mathrm{~Hz}, 2 \mathrm{H}), 7.72(\mathrm{~d}, J=8.2 \mathrm{~Hz}, 4 \mathrm{H}), 7.83(\mathrm{~d}, J$ $=8.2 \mathrm{~Hz}, 2 \mathrm{H}), 7.91(\mathrm{~d}, J=8.8 \mathrm{~Hz}, 2 \mathrm{H})$. MALDI mass-spectra $\mathrm{C}_{42} \mathrm{H}_{42} \mathrm{O}_{10} \mathrm{~S}_{2}:[\mathrm{M}]^{+} 770.36,[\mathrm{MH}]^{+}$ 771.35, $[\mathrm{M}+\mathrm{Na}]^{+}$793.38, $[\mathrm{M}+\mathrm{K}]^{+} 809.36$.

$(R)$-[(2-Methoxyphenoxy)methyl]-12-crown-4, (R)-9. General procedure for synthesis of crown-ethers

To a suspension of $\mathrm{NaH}(0.792 \mathrm{~g}, 33 \mathrm{mmol})$ in dry THF $(100 \mathrm{~mL})$ at $10{ }^{\circ} \mathrm{C}$ was added a solution of $(R)-\mathbf{1}(1.30 \mathrm{~g}, 6.6 \mathrm{mmol})$ in THF $(200 \mathrm{~mL})$ for over a period $1.5 \mathrm{~h}$. The reaction mixture was refluxed for $2.5 \mathrm{~h}$. After cooling to $25^{\circ} \mathrm{C}$, a solution of triethyleneglycol di-( $p$-toluenesulfonate) (3.01 g, $6.6 \mathrm{mmol}$, 1eq.) in THF $(250 \mathrm{~mL})$ was added to reaction mixture over a period of $3 \mathrm{~h}$. The suspension was refluxed for $70 \mathrm{~h}$. The reaction mixture was filtrated and concentrated under reduced pressure. The residue was taken up in $\mathrm{CH}_{2} \mathrm{Cl}_{2}(150 \mathrm{~mL})$ and subsequently washed with water $(3 \times 100 \mathrm{~mL})$. The organic layer was dried on $\mathrm{MgSO}_{4}$ and concentrated under reduced pressure to give yellow oil. The crude product was purified by column chromatography (silica gel, EtOAc/n-hexane $=1: 1)$ to give $(R)-9(0.31 \mathrm{~g}, 15 \%)$ as a pale yellow oil; $[\alpha]_{\mathrm{D}}{ }^{20}=+8.8(c 5$, $\left.\mathrm{CHCl}_{3}\right) .{ }^{1} \mathrm{H} \mathrm{NMR} \delta: 3.57-3.73\left(\mathrm{~m}, 12 \mathrm{H}, \mathrm{CH}_{2}\right), 3.80-3.87\left(\mathrm{~m}, 5 \mathrm{H}, \mathrm{CH}_{2}, \mathrm{OCH}_{3}\right), 3.90-4.17(\mathrm{~m}, 3 \mathrm{H}$, $\left.\mathrm{CH}, \mathrm{CH}_{2}\right), 6.85-6.91(\mathrm{~m}, 4 \mathrm{H}, \mathrm{Ar})$; MALDI mass-spectra $\mathrm{C}_{16} \mathrm{H}_{24} \mathrm{O}_{6}:[\mathrm{M}]^{+} 312.4,[\mathrm{MH}]^{+} 313.4$, [M $+\mathrm{Na}]^{+} 335.4,[\mathrm{M}+\mathrm{K}]^{+} 351.5$.

(S)-[(2-Methoxyphenoxy)methyl]-15-crown-5, (S)-10 was prepared followed the general procedure from $(S)-\mathbf{1}(1.58 \mathrm{~g}, 7.9 \mathrm{mmol})$ and tetraethyleneglycol di(p-toluenesulfonate) (4.1 g, $7.9 \mathrm{mmol})$ to yield a pale yellow oil $(0.87 \mathrm{~g}, 31 \%) ;[\alpha]_{\mathrm{D}}{ }^{20}=-13.1\left(c 1.1, \mathrm{CHCl}_{3}\right) ; 99.1 \%$ ee [chiral HPLC analysis: Chiralcel OD; n-hexane/isopropanol/Et ${ }_{2} \mathrm{NH}=80: 20: 0.1 ; t_{\mathrm{R}}=27.1 \mathrm{~min}$ (minor), $t_{\mathrm{R}}=41.0 \mathrm{~min}$ (major)]; ${ }^{1} \mathrm{H} \mathrm{NMR} \delta$ : 3.57-3.82 (m, 21H, $\left.\mathrm{CH}_{2}, \mathrm{OCH}_{3}\right), 3.90-4.08$ (m, 3H, $\left.\mathrm{CH}, \mathrm{CH}_{2}\right), 6.78-6.89$ (m, 4H, Ar). ${ }^{13} \mathrm{C} \mathrm{NMR} \delta: 57.5\left(\mathrm{OCH}_{3}\right) ; 70.0,70.7,70.81,70.83,70.85$, 
71.06, 71.13, 71.3, $71.5\left(\mathrm{CH}_{2}\right)$; $78.3(\mathrm{CH}), 112.7\left(\mathrm{C}^{3} \mathrm{Ar}\right), 114.6\left(\mathrm{C}^{6} \mathrm{Ar}\right), 121.2\left(\mathrm{C}^{4} \mathrm{Ar}\right), 121.7\left(\mathrm{C}^{5} \mathrm{Ar}\right)$, $148.9\left(\mathrm{C}^{1}{ }_{\mathrm{Ar}}\right), 150.1\left(\mathrm{C}^{2}{ }_{\mathrm{Ar}}\right)$. MALDI mass-spectra $\mathrm{C}_{18} \mathrm{H}_{28} \mathrm{O}_{7}:[\mathrm{M}]^{+} 356.6,[\mathrm{M}+\mathrm{Na}]^{+}$379.6.

$(\boldsymbol{R})$-[(2-Methoxyphenoxy)methyl]-15-crown-5, $(\boldsymbol{R})$-10. It was prepared from $(R)-\mathbf{1}$ as described for $(S)-10 ;[\alpha]_{\mathrm{D}}{ }^{20}=+13.9\left(c 1, \mathrm{CHCl}_{3}\right) ; 99.8 \%$ ee [chiral HPLC analysis: Chiralcel OD; nhexane/isopropanol/Et ${ }_{2} \mathrm{NH}=80: 20: 0.1 ; t_{\mathrm{R}}=41.5 \mathrm{~min}$ (minor), $t_{\mathrm{R}}=26.5 \mathrm{~min}$ (major)]. NMR spectra were identical with those cited for $(S)-\mathbf{1 0}$.

(S)-[(4-Methoxyphenoxy)methyl]-15-crown-5, (S)-10a. The compound was prepared according to a published method ${ }^{8 b}$ from $(S)$-3-(4-methoxyphenoxy)propane-1,2-diol $(S)$-1a (1.3 $\mathrm{g}, 6.56 \mathrm{mmol})$ and tetraethyleneglycol $\mathrm{di}(p$-toluenesulfonate) $(3.34 \mathrm{~g}, 6.6 \mathrm{mmol})$ to give $0.93 \mathrm{~g}$ $(40 \%)$ of pure product as a pale yellow oil; $[\alpha]_{\mathrm{D}}{ }^{20}=-13.8\left(c 6.9, \mathrm{CHCl}_{3}\right) ;\left\{\right.$ lit. $^{8 \mathrm{a}}[\alpha]_{\mathrm{D}}{ }^{20}=-14.5(c$ 7, $\left.\left.\mathrm{CHCl}_{3}\right)\right\} .{ }^{1} \mathrm{H}$ NMR $\delta: 3.65-3.75\left(\mathrm{~m}, 16 \mathrm{H}, \mathrm{CH}_{2}\right), 3.77\left(\mathrm{~s}, 3 \mathrm{H}, \mathrm{OCH}_{3}\right), 3.79-3.91(\mathrm{~m}, 5 \mathrm{H}, \mathrm{CH}$, $\left.\mathrm{CH}_{2}\right), 6.81-6.87$ (m, 4H, Ar).

$(R)-12-[(2-M e t h o x y p h e n o x y) m e t h y l]-2,3-b e n z o-18-c r o w n-6,(R)-11 a$ was prepared in a manner similar to that described for the preparation of $(R)-9$ by using diol $(R)-3(1.3 \mathrm{~g}, 4.5$ mmol), suspension of $\mathrm{NaH}(0.79 \mathrm{~g}, 19.9 \mathrm{mmol}, 60 \%$ in mineral oil) and 1,2-bis-[2- $(p$ tolylsulfonyl)ethoxy]benzene ${ }^{8 \mathrm{a}} \mathbf{6 a}(2.3 \mathrm{~g}, 4.5 \mathrm{mmol})$ to yield $0.3 \mathrm{~g}(15 \%) ;[\alpha]_{\mathrm{D}}{ }^{20}=+5.7(c 1.8$, $\left.\mathrm{CHCl}_{3}\right) .{ }^{1} \mathrm{H}$ NMR $\delta$ : 3.70-3.95 (m, 16H), 4.08-4.22 (m, 8H), 6.88-6.92 (m, 8H, Ar). MALDI mass-spectra $\mathrm{C}_{24} \mathrm{H}_{32} \mathrm{O}_{8}:[\mathrm{M}]^{+}$447.93, $[\mathrm{M}+\mathrm{Na}]^{+}$470.96, $[\mathrm{M}+\mathrm{K}]^{+} 486.94$.

(S)-12-[(2-Methoxyphenoxy)methyl]-2,3-naphtho-18-crown-6, $(S)$-11b was prepared in a manner similar to that described for the preparation of $(R)-9$ by using diol $(S)-3(1.14 \mathrm{~g}, 4 \mathrm{mmol})$, suspension of $\mathrm{NaH}(0.71 \mathrm{~g}, 17.7 \mathrm{mmol}, 60 \%$ in mineral oil $)$ and 2,3-bis-[2- $(p$ tolylsulfonyl)ethoxy]naphthalene ${ }^{8 \mathrm{a}} \mathbf{6 b}(2.22 \mathrm{~g}, 4 \mathrm{mmol})$. The crude product as a viscous oil was purified by silica gel column chromatography (eluent: hexane/EtOAc from 96:4 until 20:80) to yield $0.42 \mathrm{~g}(21.5 \%)$. Mp 88-90 ${ }^{\circ} \mathrm{C}(\mathrm{EtOH}) ;[\alpha]_{\mathrm{D}}{ }^{20}=-6.0\left(c 1.5, \mathrm{CHCl}_{3}\right) .95 \%$ ee [chiral HPLC analysis: Chiralcel OD; n-hexane/isopropanol/Et ${ }_{2} \mathrm{NH}=80: 20: 0.1 ; t_{\mathrm{R}}=41.7 \mathrm{~min}$ (major), $t_{\mathrm{R}}=$ $47.1 \mathrm{~min}$ (minor)]. ${ }^{1} \mathrm{H}$ NMR $\delta: 3.70-3.82(\mathrm{~m}, 12 \mathrm{H}), 3.91-4.07(\mathrm{~m}, 8 \mathrm{H}), 4.22-4.30(\mathrm{~m}, 4 \mathrm{H}), 6.80-$ $6.87(\mathrm{~m}, 4 \mathrm{H}), 7.10(\mathrm{~d}, J=4.0 \mathrm{~Hz}, 2 \mathrm{H}), 7.31(\mathrm{dd}, J=3.1,5.8 \mathrm{~Hz}, 2 \mathrm{H}), 7.64(\mathrm{dd}, J=3.6,5.8 \mathrm{~Hz}$, $2 \mathrm{H}) .{ }^{13} \mathrm{C}$ NMR $\delta: 56.0\left(\mathrm{CH}_{3} \mathrm{O}\right) ; 68.87,68.94,69.31,69.45,69.61,70.40,71.02,71.14,71.29$, $71.70\left(\mathrm{CH}_{2}\right) ; 78.03(\mathrm{CH}) ; 108.02,108.22,110.0,112.33,114.27,120.94,121.45,124.14,126.30$, 126.36, 129.35, 129.37, 148.57, 149.21, 149.22, 149.78. EI mass-spectrum [m/z(I\%)] $\mathrm{C}_{28} \mathrm{H}_{34} \mathrm{O}_{8}$ : 499(12), 498(43), 231(16), 213(13), 199(12), 188(8), 187(67), 186(71), 185(10), 171(41), 163(31), 160(9), 159(11), 145(9), 141(6), 131(12), 122(7), 115(11), 102(11), 101(53), 89(16), 87(16), 77(11), 73(11), 59(19), 57(24), 45(100), 43(12), 41(17), 31(13). MALDI mass-spectrum $[\mathrm{M}]^{+}$498.3, $[\mathrm{MH}]^{+}$499.3, $[\mathrm{M}+\mathrm{Na}]^{+}$521.3, $[\mathrm{M}+\mathrm{K}]^{+}$537.3.

(R)-12-[(2-Methoxyphenoxy)methyl]-2,3-naphtho-18-crown-6, $(R)-11 b$ was prepared by analogy with a general procedure, from $1.62 \mathrm{~g}(8.17 \mathrm{mmol})$ of $(R)-\mathbf{1}$, suspension of $1.45 \mathrm{~g}(36.12$ $\mathrm{mmol}, 60 \%$ in mineral oil $)$ of $\mathrm{NaH}$ and $5.26 \mathrm{~g}(8.17 \mathrm{mmol})$ of $\mathbf{8 b}$. The crude product $(5.75 \mathrm{~g})$ was purified by silica gel column chromatography (eluent: light petroleum/EtOAc from 10:1 until 1:10). The yield was $1.8 \mathrm{~g}(44.2 \%) ; \mathrm{Mp} 88-90{ }^{\circ} \mathrm{C}(\mathrm{EtOH}) ;[\alpha]_{\mathrm{D}}{ }^{20}=+5.5\left(c \mathrm{cos}, \mathrm{CHCl}_{3}\right) ; 94 \%$ ee [chiral HPLC analysis: Chiralcel OD; n-hexane/isopropanol/Et ${ }_{2} \mathrm{NH}=80: 20: 0.1 ; t_{\mathrm{R}}=42.4 \mathrm{~min}$ 
(major), $t_{\mathrm{R}}=47.7$ min (minor)]. NMR spectra were identical with these cited above for $(S)-\mathbf{1 1 b}$. MALDI mass-spectrum $[\mathrm{M}]^{+}$498.3, $[\mathrm{MH}]^{+}$499.3, $[\mathrm{M}+\mathrm{Na}]^{+}$521.3, $[\mathrm{M}+\mathrm{K}]^{+}$537.3.

(aS,S)-14-[(2-Methoxyphenoxy)methyl]-2,3:4,5-di(1,2-naphtho)-20-crown-6,

$(\mathbf{a} S, S)-11 \mathrm{c}$.

Method A. (aS,S)-11c was prepared by analogy with the general procedure, from $(S)-3(1.50 \mathrm{~g}$, $5.25 \mathrm{mmol})$ and $(\mathbf{a S})-6 \mathrm{c}(3.40 \mathrm{~g}, 4.99 \mathrm{mmol})$ to give $0.56 \mathrm{~g}(17 \%)$ of pure product as a pale yellow oil; $[\alpha]_{\mathrm{D}}{ }^{20}=-73.1$ (c 1.0, THF); $98.5 \%$ ee [chiral HPLC analysis: Chiralcel OD; nhexane/isopropanol/ $/ \mathrm{Et}_{2} \mathrm{NH}=80: 20: 0.1 ; t_{\mathrm{R}}=43.0 \mathrm{~min}$ (minor), $t_{\mathrm{R}}=56.1 \mathrm{~min}$ (major) $] .{ }^{1} \mathrm{H} \mathrm{NMR}$ $\delta$ : 3.37-3.81 (m, 20H, $\left.\mathrm{OCH}_{2} \mathrm{CH}_{2} \mathrm{O}\right), 3.87$ (s, OMe), 3.98-4.12 (m, 5H), 4.15-4.25 (m, 2H), 6.88$6.98(\mathrm{~m}, 4 \mathrm{H}), 7.15(\mathrm{~d}, J=8.6 \mathrm{~Hz}, 2 \mathrm{H}), 7.21(\mathrm{dd}, J=8.1,8.7 \mathrm{~Hz}, 2 \mathrm{H}), 7.31-7.35(\mathrm{~m}, 2 \mathrm{H}), 7.45$ $(\mathrm{d}, J=8.5 \mathrm{~Hz}, 1 \mathrm{H}), 7.49(\mathrm{~d}, J=9.0 \mathrm{~Hz}, 1 \mathrm{H}), 7.86(\mathrm{~d}, J=8.1 \mathrm{~Hz}, 2 \mathrm{H}), 7.94(\mathrm{~d}, J=9.0 \mathrm{~Hz}, 2 \mathrm{H})$. ${ }^{13} \mathrm{C}$ NMR $\delta$ : $56.0\left(\mathrm{CH}_{3} \mathrm{O}\right) ; 69.33,69.80,69.88,70.07,70.10,70.16,70.63,70.94,71.43,71.50$ $\left(\mathrm{CH}_{2}\right)$; $77.63(\mathrm{CH}) ; 112.35,114.28,115.85,116.87,120.47,120.97,121.52,123.50,123.60$, $123.68,125.42$, 125.50, 126.16, 126.22, 127.81, 127.85, 129.19, 129.30, 129.42, 129.58, 129.67, 134.13, 148.56, 149.81, 154.44, 154.71. EI mass-spectrum $\mathrm{C}_{38} \mathrm{H}_{40} \mathrm{O}_{8}[\mathrm{~m} / \mathrm{z}(\mathrm{I} \%)]:$ 625(51), 624(100), 313(29), 312(16), 199(23), 181(7), 163(18), 158(6), 157(24), 155(210), 145(10), 141(10), 135(8), 121(8), 113(8), 101(34), 92(6), 91(27), 87(10), 83(6), 73(11), 65(14), 59(11), 57(30), 45(79), 43(12), 41(18), 31(15). MALDI mass-spectrum $[\mathrm{M}]^{+}$624.4, $[\mathrm{MH}]^{+}$625.4, $[\mathrm{M}+$ $\mathrm{Na}]^{+}$647.4, $[\mathrm{M}+\mathrm{K}]^{+} 663.5$.

$(\mathrm{a} R, R)-14-[(2-M e t h o x y p h e n o x y) m e t h y l]-2,3: 4,5-d i(1,2-n a p h t h o)-20-c r o w n-6, \quad(a R, R)-11 c$ was prepared in a manner similar to that described for the preparation of $(\mathrm{a} S, S)$-11c (method A); $[\alpha]_{\mathrm{D}}^{20}=+74.2$ (c 1, THF), $99.1 \%$ ee [chiral HPLC analysis: Chiralcel OD; nhexane/isopropanol/ $\mathrm{Et}_{2} \mathrm{NH}=80: 20: 0.1 ; t_{\mathrm{R}}=46.9 \mathrm{~min}$ (major), $t_{\mathrm{R}}=54.6 \mathrm{~min}$ (minor)]. NMR spectra were identical with these cited above for $(\mathrm{a} S, S)$-11c.

Method B. (aR,R)-11c was prepared by analogy with the general procedure, from $(R)-1(1.50 \mathrm{~g}$, $7.57 \mathrm{mmol})$ and $(\mathrm{a} R)-8 \mathrm{c}(3.54 \mathrm{~g}, 6.93 \mathrm{mmol})$ to yield $1.77 \mathrm{~g}(41 \%)$ of a pale yellow oil; $[\alpha]_{\mathrm{D}}{ }^{20}=$ +74.1 ( $c$ 1.0, THF). ${ }^{1} \mathrm{H}$ NMR spectrum was identical with those cited above.

\section{NMR experiments}

Self-diffusion coefficients determination. The 2D DOSY experiments were performed by STEBPLED sequence. ${ }^{26}$ Data was acquired with a 20-50 ms diffusion delay in all experiments, bipolar gradient pulses duration from 2.3 to $3.5 \mathrm{~ms}$ (depending on a system under investigation), $1 \mathrm{~ms}$ spoil gradient pulse $(30 \%)$ and a $5 \mathrm{~ms}$ eddy current delay. The bipolar pulse gradient strength was varied incrementally from 0.01 to $0.32 \mathrm{~T} / \mathrm{m}$. The experimentally observed diffusion coefficients were then determined from 2D DOSY plots obtained by Bruker XWinNmr software package. Several measures of $\mathrm{D}$ were obtained at more than one place in the spectrum and all experiments were carried out in duplicate or triplicate mode. The reported results are the mean value of multiple data points and the standard deviations are less than $0.05 \cdot 10^{-9} \mathrm{~m}^{2} / \mathrm{s}$ in all cases. The temperature was set and controlled at $298 \mathrm{~K}$ with a $535 \mathrm{l} / \mathrm{h}$ airflow rate in order to avoid any temperature fluctuations owing to sample heating during the magnetic field pulse gradients. 
Amine or amino acid ester salts extraction runs reported in Table 2. Run 5. The $0.6 \mathrm{ml}$ of $\mathrm{D}_{2} \mathrm{O}$ solution contained $4.4 \mathrm{mg}(0.029 \mathrm{mmol})$ of $\mathrm{LiPF}_{6}$ and $4.6 \mathrm{mg}(0.029 \mathrm{mmol})$ of $(S)$ phenylethylammonium hydrochloride $(S)-\mathbf{1 4} \cdot \mathrm{HCl}$ was shaken for $1 \mathrm{~min}$ at r.t. with $0.8 \mathrm{ml}$ of $(S)$ $10(2.8 \mathrm{mg}, 0.0078 \mathrm{mmol})$ in $\mathrm{CDCl}_{3}(0.01 \mathrm{M})$. The organic layer was dried $\left(\mathrm{MgSO}_{4}\right)$ and the spectrum taken. The runs 1-4 and 6-22 were carried by analogy with the corresponding host and guest.

Extraction, isolation, and rotation experiment of methyl phenylglicinate hexafluorophosphate

Host (aS,S)-11c $\left(80 \mathrm{mg}, 0.128 \mathrm{mmol}\right.$ ) was dissolved in $0.7 \mathrm{ml}$ of $\mathrm{CDCl}_{3}$ to give a $0.18 \mathrm{M}$ solution. This solution was used to extract 3 eq. of racemic methyl phenylglicinate hydrochloride rac-13. $\mathrm{HCl}(77.2 \mathrm{mg}, 0.383 \mathrm{mmol})$ dissolved in $0.4 \mathrm{ml}$ of an aqueous $\mathrm{D}_{2} \mathrm{O}$ solution $(0.92 \mathrm{M}$ in guest) contained $0.0582 \mathrm{~g}(0.383 \mathrm{mmol})$ of $\mathrm{LiPF}_{6}$. After equilibration at r.t. (about $\left.30 \mathrm{~min}\right)$, the phases were carefully separated, and the meniscus was discarded. The organic phase was diluted with $1 \mathrm{ml}$ of $\mathrm{CH}_{2} \mathrm{Cl}_{2}$ and extracted with three $0.8 \mathrm{ml}$ portions of $0.1 \mathrm{~N} \mathrm{HCl}$. The combined aqueous extracts were added to $2.6 \mathrm{ml}$ of $\mathrm{CH}_{2} \mathrm{Cl}_{2}$ and aqueous ammonium hydroxide was added to adjust the $\mathrm{pH}$ to 10 . The organic phase was withdrawn, the aqueous phase was reextracted with another $1.5 \mathrm{ml}$ of $\mathrm{CH}_{2} \mathrm{Cl}_{2}$, and the combined organic extracts were dried with $\mathrm{MgSO}_{4}$. The solvent was evaporated to give $10 \mathrm{mg}$ of the amino ester 13 as an oil $(0.06 \mathrm{mmol}) ;[\alpha]_{\mathrm{D}}{ }^{20}=-40$ $\left(0.3, \mathrm{CHCl}_{3}\right) ;[\alpha]_{\mathrm{D}}{ }^{20}=-33,[\alpha]_{578}{ }^{20}=-35,[\alpha]_{546}{ }^{20}=-39,[\alpha]_{436}{ }^{20}=-76\left(\mathrm{c} 0.3, \mathrm{CH}_{2} \mathrm{Cl}_{2}\right)$, indicating an optical purity of $20-22 \%$, enriched in the $(R)$-enantiomer. $\left\{\right.$ Cf. lit. $^{4}[\alpha]_{578^{20}}=-52.5,[\alpha]_{546}{ }^{20}=-$ $60.4,[\alpha]_{436}{ }^{20}=-110.6$ (c 2, $\mathrm{CH}_{2} \mathrm{Cl}_{2}$ ), for D-13, $32.6 \%$ op $\}$. \{Cf. lit. ${ }^{27}$ for $(S)$-phenylglycine methyl ester: $\left.[\alpha]_{\mathrm{D}}{ }^{20}=202.3\left(0.49, \mathrm{CHCl}_{3}\right)\right\} .{ }^{1} \mathrm{H}$ NMR $\delta: 1.88$ (b.s, 2H), 3.77 (s, 3H), 4.65 (s, 1H), 7.28-7.38 (m, 5H). Examination of the NMR spectrum of this product showed the absence of 11c signals.

\section{Acknowledgements}

We gratefully acknowledge the Russian Foundation for Basic Research (Grant \# 09-03-00123-a) for the financial support of this work. This investigation was partly carried out in the NMR Department (A. E. Arbuzov Institute of Organic and Physical Chemistry) of the Federal collective spectral analysis center for physical and chemical investigations of structure, properties and composition of matter and materials. 


\section{References}

1. For recent reviews see (a) Zhang, M.; Zhu, K.; Huang, F. Chem. Commun. 2010, 46, 8131. (b) Tsukanov, A. V.; Dubonosov, A. D.; Bren, V. A.; Minkin, V. I. Chem. Heterocyclic Comp. 2008, 44, 899. (c) Gokel, G. W.; Leevy, W. M.; Weber, M. E. Chem. Rev. 2004, 104, 2723.

2. For reviews see (a) Hyun, M. H. Bull. Korean Chem. Soc. 2005, 29, 1153. (b) Hyun, M. H. J. Separation Sci. 2003, 26, 242. (c) Gao, M.-Z.; Yang, Y.-O.; Xu, Z.-L. Chinese J. Org. Chem. 2001, 21, 477. (d) Stoddart, J. F. Top. Stereochem. 1988, 17, 207.

3. Kyba, E. P.; Koga, K.; Sousa, L. R.; Siegel, M. G.; Cram, D. J. J. Am. Chem. Soc. 1973, 95, 2692.

4. Kyba, E. P.; Timko, J. M.; Kaplan, L. J.; de Jong, F.; Gokel, G. W.; Cram, D. J. J. Am. Chem. Soc. 1978, 100, 4555.

5. For reviews see (a) Spath, A.; Knig, B. Beilstein J. Org. Chem. 2010, no. 32., p 111. (b) Zhang, X. X.; Bradshaw, J. S.; Izatt, R. M. Chem. Rev. 1997, 95, 3313.

6. For recent examples see (a) Kertesz, J.; Huszthy, P.; Kormos, A.; Bertha, F.; Horvath, V.; Horvai, G. Tetrahedron: Asymmetry 2009, 20, 2795. (b) Wenzel, T. J.; Bourne, C. E.; Clark, R. L. Tetrahedron: Asymmetry 2009, 20, 2052. (c) Nakatsuji, Y.; Nakahara, Y.; Muramatsu, A.; Kida, T.; Akashi, M. Tetrahedron Lett. 2005, 46, 4331.

7. (a) Gokel, G. W.; Schall, O. F. In Lariat Ethers; Gokel, G. W., Ed. Comprehensive Supramolecular Chemistry. Pergamon: New York, 1996; pp 97-152. (b) Elwahy, A. H. M.; Abbas, A. A. J. Heterocyclic Chem. 2008, 45, 1. (c) Abbas, A. A.; Elwahy, A. H. M. J. Heterocyclic Chem. 2009, 46, 1035.

8. (a) Karakaplan, M.; Aral, T.; Tetrahedron: Asymmetry 2005, 16, 2119. (b) Aydin, Y.; Aral, T.; Karakaplan, M.; Hosgoren, H.; Tetrahedron: Asymmetry 2009, 20, 179.

9. Gokel, G. W.; Dishong, D. M.; Diamond, C. J. Chem. Commun. 1980, 1053.

10. Bredikhina, Z. A.; Novikova, V. G.; Zakharychev, D. V.; Bredikhin, A. A. Tetrahedron: Asymmetry 2006, 17, 3015.

11. Kyba, E. P.; Gokel, G. W.; de Jong, F.; Koga, K.; Sousa, L. R.; Siegel, M. G.; Kaplan, L.; Sogah, G. D. Y.; Cram, D. J. J. Org. Chem. 1977, 42, 4173.

12. de Vries, E. F. V.; Steenwinkel, P.; Brussee, J.; Kruse, C. G.; van der Gen, A. J. Org. Chem. 1993, 58, 4315.

13. Stock, H. Th.; Kellogg, R. M. J. Org. Chem. 1996, 61, 3093.

14. (a) Price, W. S. Conc. Magn. Reson., 1997, 9, 299. (b) Johnson, C. S. Jr. Prog. Nucl. Magn. Reson. Spectrosc. 1999, 34, 203. (c) Antalek, B. Conc. Magn. Reson. 2002, 14, 225. (d) Kharlamov, S. V.; Latypov, Sh. K. Russian Chem. Rev. 2010, 79, 635.

15. (a) Cohen, Y.; Avram, L.; Evan-Salem, T.; Frish, L. In Analytical Methods in Supramolecular Chemistry; Schalley, Ch. A., Ed.; Wiley: Weinheim, 2007, 163. (b) Pastor, A.; Martinez-Viviente, E. Coord. Chem. Rev. 2008, 252, 2314. 
16. Bredikhin, A. A.; Bredikhina, Z. A.; Novikova, V. G.; Pashagin, A. V.; Zakharychev, D. V.; Gubaidullin, A. T. Chirality 2008, 20, 1092.

17. Bredikhin, A. A.; Strunskaya, E. I.; Novikova, V. G.; Azancheev, N. M.; Sharafutdinova, D. R; Bredikhina, Z. A. Rus. Chem. Bull., Int. Ed. 2004, 53, 213.

18. Chen, J.; Shum, W. A. Tetrahedron Lett. 1995, 36, 2379.

19. Theil, F.; Weidner, J.; Ballschun, S.; Kunath, A.; Schick, H. J. Org Chem. 1994, 59, 388.

20. Pummerer, R.; Prell, E.; Rieche, A. Ber. 1926, 59, 2159.

21. Kawashima, M.; Hirata, R. Bull. Chem. Soc. Jpn. 1993, 66, 2002.

22. The Merck Index, $14^{\text {th }}$ Ed., O'Neil, M. J., Ed. Merck and Co., Inc., Whitehouse Station, NJ, USA, 2006; 14, 1226.

23. Widhalm, M.; Klintschar, G. Chem. Ber. 1994, 127, 1411.

24. Czech, B.; Czech, A.; Bartsch, R. A. J. Heterocyclic Chem., 1984, 21, 341.

25. Kyba, E. P.; Gokel, G. W.; Jong, F.; Koga, K.; Sousa, L. R.; Siegel, M. G.; Kaplan, L.; Sogah, G. D. Y.; Cram, D. J. J. Org. Chem. 1977, 42, 4173.

26. Wu, D.; Chen, A.; Johnson, C.S. Jr. J. Magn. Reson. A. 1995, 115, 260.

27. Shang, G.; Yang, Q.; Zhang, X. Angew. Chem. Int. Ed. 2006, 45, 6360. 